\title{
Penerapan Ragam Hias Arsitektur Betawi Pada Gaya Interior Modern Dalam Perancangan Interior Perpustakaan Umum Daerah Provinsi DKI Jakarta - Cikini
}

\author{
Kevin Junianto ${ }^{1}$, Hartini Laswandi ${ }^{2}$, M. Taufiq ${ }^{3}$ \\ Prodi Desain Interior, Fakultas Seni Rupa dan Desain, Universitas Tarumanagara, Jakarta \\ kevin.615160088@stu.untar.ac.id, hartini@fsrd.untar.ac.id,mtaufiq@dtt.untar.ac.id
}

\begin{abstract}
Abstrak - Perpustakaan Umum Daerah Provinsi DKI Jakarta - Cikini merupakan satu dari beberapa perpustakaan dibawah naungan Dinas Perpustakaan dan Kearsipan Provinsi DKI Jakarta (DISPUSIP DKI) yang terletak di kompleks Taman Ismail Marzuki (TIM). Penelitian ini ditujukan untuk mengetahui bagaimana hasil penerapan unsur ragam hias arsitektur budaya lokal Jakarta yaitu budaya Betawi Bila diterapakan kedalam rancangan interior bergaya modern pada area khusus ruang lobby resepsionis dan ruang koleksi pustaka umum Perpustakaan Umum Daerah Provinsi DKI Jakarta - Cikini. Metode yang digunakan pada penelitian ini adalah kualitatif deskriptif yang bersifat menggambarkan, memaparkan, menganalisis, dan menyimpulkan data sehingga diperoleh suatu pendekatan untuk selanjutnya digunakan dalam penyusunan laporan. Pada bagian berikutnya berisi gambar-gambar penerapan unsur ragam hias arsitektur yang diterapkan pada perancangan area lobby resepsionis, dan area baca koleksi Perpustakaan Umum Daerah Provinsi DKI Jakarta - Cikini. Dan disimpulkan bahwa penerapan ragam hias Betawi pada interior bergaya modern dapat memberikan nilai estetik lebih dan identitas ornamen arsitektur kebudayaan lokal.
\end{abstract}

Kata Kunci : Desain Interior, Ragam Hias Betawi, Perpustakaan Umum Daerah

\section{PENDAHULUAN}

Perpustakaan adalah tempat dimana berbagai jenis koleksi informasi dan ilmu pengetahuan misalnya buku, majalah, jurnal, buku elektronik, ensiklopedia, compact disc (CD) dsb yang disimpan dan dirawat agar dapat dikonsumsi oleh khalayak umum sebagai ruang sumber pencarian informasi dan ilmu pengetahuan. Terbatasnya ekonomi, tingkat literatur, sumber pengetahuan dan informasi di masyarakat mendorong didirikannya perpustakaan sebagai ruang masyarakat untuk menimba ilmu sebanyak mungkin dengan keterbatasan tersebut.
Perpustakaan Umum Daerah Provinsi DKI Jakarta - Cikini merupakan satu dari beberapa perpustakaan yang dikelola oleh pemerintah DKI Jakarta yang berada di kompleks Taman Ismail Marzuki, Jl. Cikini Raya - Jakarta Pusat. Lokasi perpustakaan ini yang terletak di Jakarta dan berada dibawah naungan pemerintah DKI Jakarta menciptakan pemikiran mengenai bagaimana hasil rancangan desain interior yang menggabungkan antara unsur kebudayaan lokal Jakarta yaitu Betawi dan gaya desain interior modern yang umum dan banyak digunakan pada saat ini di Jakarta. Selain itu juga diharapkan jurnal ini 
dapat membangkitkan kembali semangat penerapan dan penggunaan unsur ragam hias arsitektur Betawi di Jakarta khususnya pada penerapan gaya interior modern yang saat ini banyak digunakan di area Jakarta.

"Secara umum bentuk arsitektur bangunan rumah Betawi memiliki ciri yaitu terdapat lisplang yang disebut sebagai gigi balang. Lisplang ini diletakkan pada bagian atas/atap rumah. Pagar teras yang disebut langkan merupakan pembatas teras yang terbuat dari kayu dan menyerupai pagar, tetapi berada diluar teras" (Fajriyah, 2014).

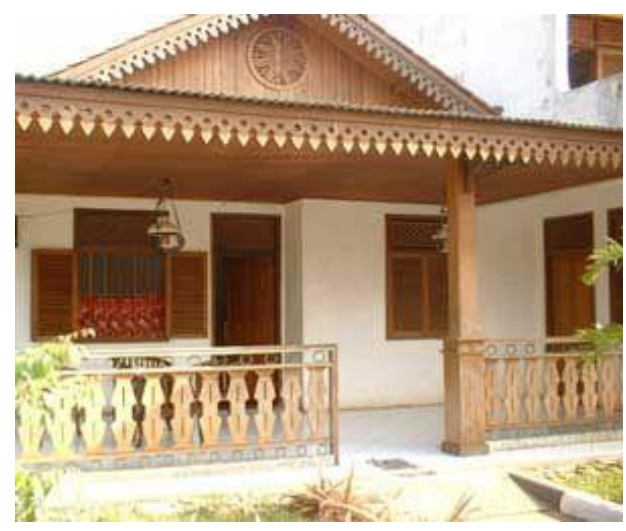

Gambar 1. Fasad Rumah Betawi

kumpulanmateripelajaranpoputer1013.blogspot.com

Pada rumah Betawi, terdapat pintu yang berupa pintu krepyak/jalusi dan dua jenis jendela yang umum ditemukan yaitu jendela krepyak/jalusi yaitu jendela dengan motif garis-garis sirkulasi angin horizontal, dan jendela bujang/jejake yang merupakan jendela dengan ventilasi vertikal. "Bagi individu yang mampu jeruji ini terbuat dari besi, namun bagi individuyang tidak mampu, jerujinya terbuat dari kayu." (Sheha \& Ghoustanjiwani A.P, 2011). “Jendela jejake adalah jendela tanpa daun jendela dan hanya dilengkapi dengan balustrade (kisi). jendela ini juga disebut jendela intip dikarenakan pada zaman dahulu pria bujang hanya boleh melihat dan berbicara dengan anak gadis melalui jendela ini" (Swadarma \& Aryanto, 2013).

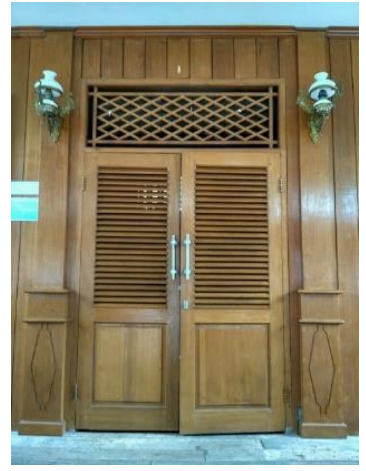

Gambar 2 Pintu Krepyak/Jalusi Betawi keramikcorak.blogspot.com

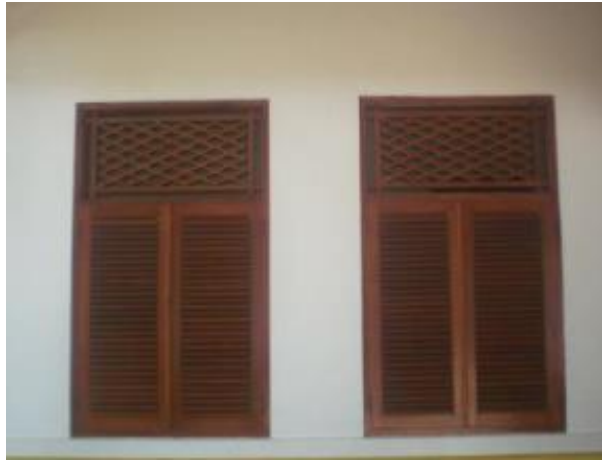

Gambar 3. Jendela Krepyak/Jalusi Betawi (Fajriyah, 2014) 


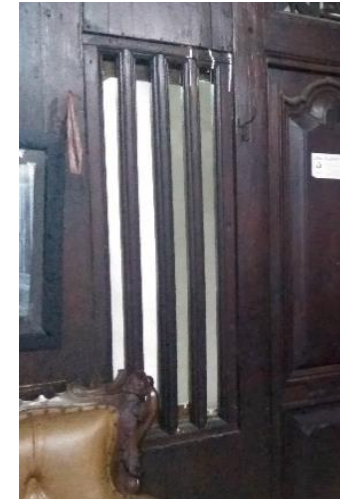

Gambar 4. Jendela Bujang/Jejake Betawi validnews.id

Ornamen-ornamen yang terdapat pada rumah Betawi "berupa olah geometris flora, fauna, dan ornamen lain. Ornamen-ornamen tersebut diantaranya adalah bunga melati, bunga cempaka, bunga kenanga, bunga matahari, bentuk tumpal, simbol matahari, gigi balang, pucuk rebung" (Kurniati, B. Amiuza, \& Suryasari, 2017).

Tabel 1: Ornamen Rumah Betawi

\begin{tabular}{|c|c|l|}
\hline No & Ornamen Rumah & Contoh Hasil Penerapan \\
\hline 1 & Bunga cempaka & Pada area atap \\
\hline 2 & Bunga matahari & Pada tiang kolom \\
\hline 3 & Bunga melati & Pada ventilasi udara \\
\hline 4 & Matahari & Pada ventilasi udara \\
\hline
\end{tabular}

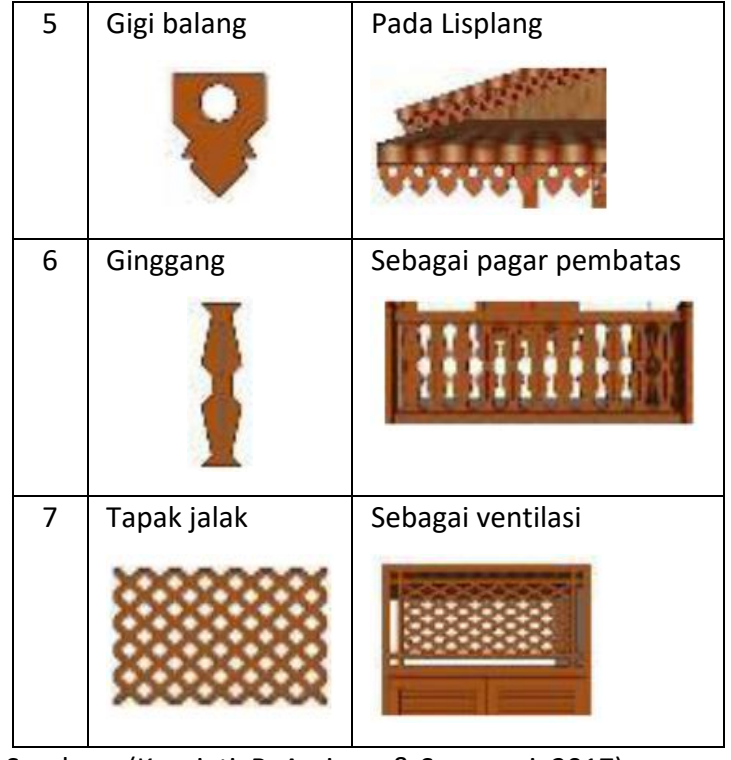

Sumber : (Kurniati, B. Amiuza, \& Suryasari, 2017)

Berdasarkan latar belakang masalah yang telah disebutkan diatas, maka ditetapkan tujuan dari penelitian ini, diantaranya:

1. Mengetahui bagaimana hasil penerapan ragam hias arsitektur Betawi ke dalam interior bergaya modern dalam pemberian identitas kebudayaan lokal terhadap perpustakaan.

2. Mengetahui apakah penerapan ragam hias arsitektur Betawi akan cocok bila diterapkan kedalam interior bergaya modern.

\section{METODE}

Metode yang digunakan pada penelitian ini adalah kualitatif deskriptif yang bersifat menggambarkan, memaparkan, menganalisis, dan 
menyimpulkan data sehingga diperoleh suatu pendekatan untuk selanjutnya digunakan dalam penyusunan laporan. Metode ini digunakan sesuai dengan tujuan yaitu menjabarkan penerapan ornamen arsitektur Betawi kedalam gaya interior modern pada interior ruang lobby resepsionis dan ruang koleksi pustaka umum pada Perpustakaan Umum Daerah Provinsi DKI Jakarta - Cikini.

Untuk mendukung penelitian ini dilakukan pengumpulan data melalui studi dokumen dalam rupa jurnal dan laman daring (online) yang digunakan sebagai sumber bahan analisis.

Proses penelitian ini akan terdiri dari beberapa tahap yaitu; (1) pengumpulan data, yang digunakan sebagai bahan sumber informasi; (2) reduksi data, yaitu proses pemilihan dan pemilahan data; (3) penyajian data, dimana penyajian data ini akan bersifat deskriptif; (4) analisis data, proses penganalisaan dan pemaparan objek penelitian dalam bentuk paragraf deskriptif; (5) kesimpulan, penarikan kesimpulan terkait.

\section{HASIL DAN PEMBAHASAN}

Berikut adalah hasil penerapan ragam hias arsitektur Betawi ke dalam interior bergaya modern dalam proyek perancangan interior Perpustakaan Umum
Daerah Provinsi DKI Jakarta - Cikini pada area ruang khusus lobby resepsionis dan ruang koleksi pustaka umum.

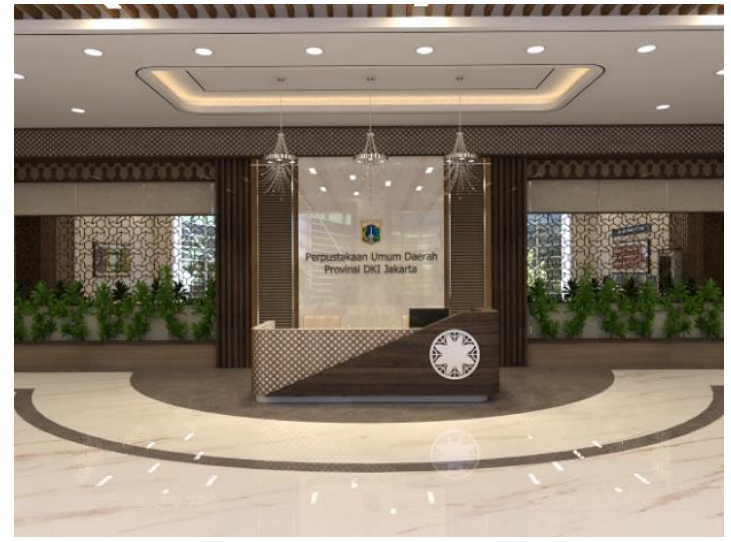

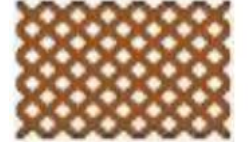

(a)

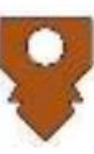

(b)

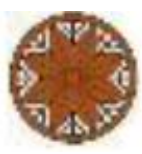

(c)

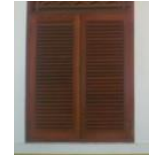

(d)
Gambar 5. Hasil Perancangan Interior Lobby Resepsionis. (a) Tapak Jalak, (b) Gigi Balang, (c) Bunga Cempaka, (d) krepyak/Jalusi

Pada gambar area lobby resepsionis dapat dilihat penerapan ragam hias Betawi pada area backdrop dan meja resepsionis. Pada area backdrop bagian terdapat penerapan ragam hias tapak jalak yang kemudian pada bagian bawahnya diterapkan ragam hias gigi balang. Pada panel vertikal dibelakang meja resepsionis diberikan panel yang dirancang memiliki tampilan ventilasi terinspirasi dari jendela/pintu krepyak. Meja resepsionis diberikan unsur dekorasi berupa laser cutting tapak jalak dan dekorasi bunga cempaka. 


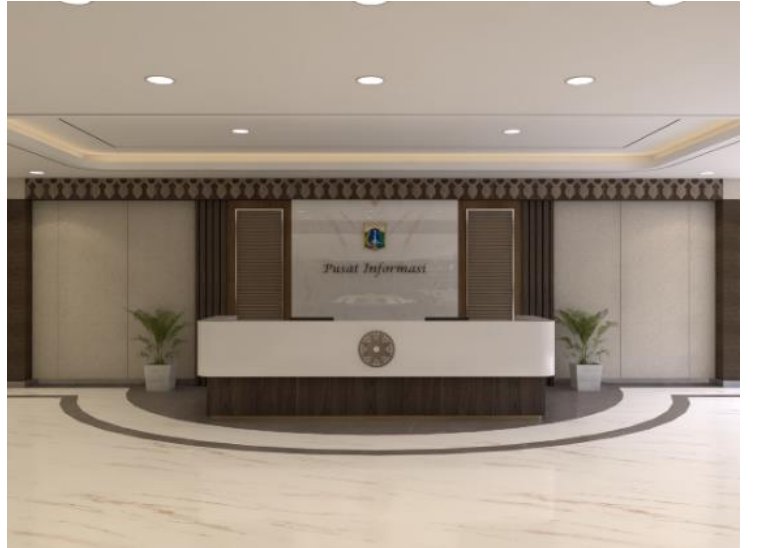

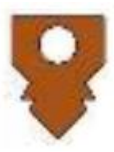

(a)

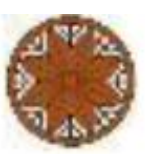

(b)

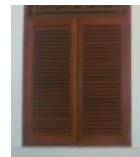

(c)
Gambar 6. Hasil Perancangan Interior Area Koleksi Pustaka Umum (Area Informasi). (a) Gigi Balang, (b) Bunga Cempaka, (c) krepyak/Jalusi

Pada area ruang koleksi pustaka umum pada bagian menghadap meja informasi terdapat penerapan ragam hias gigi balang pada pertemuan dinding dan plafon, terdapat penggunaan kembali panel krepyak/jalusi pada backdrop area informasi, dan meja informasi yang diberikan hiasan ornamen bungan cempaka.

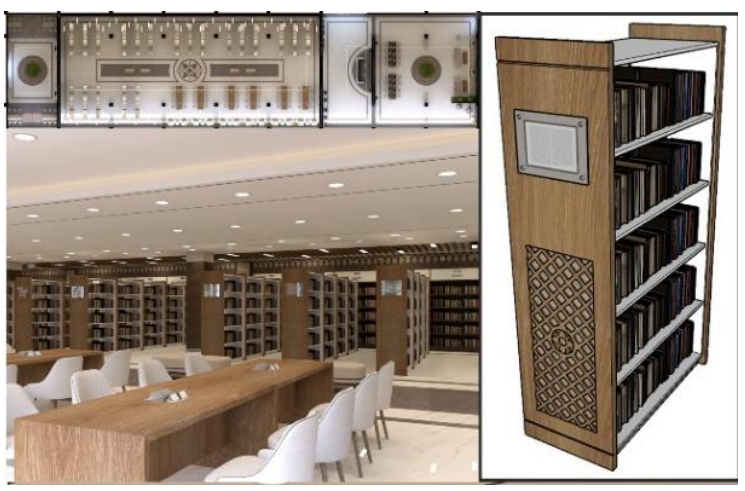

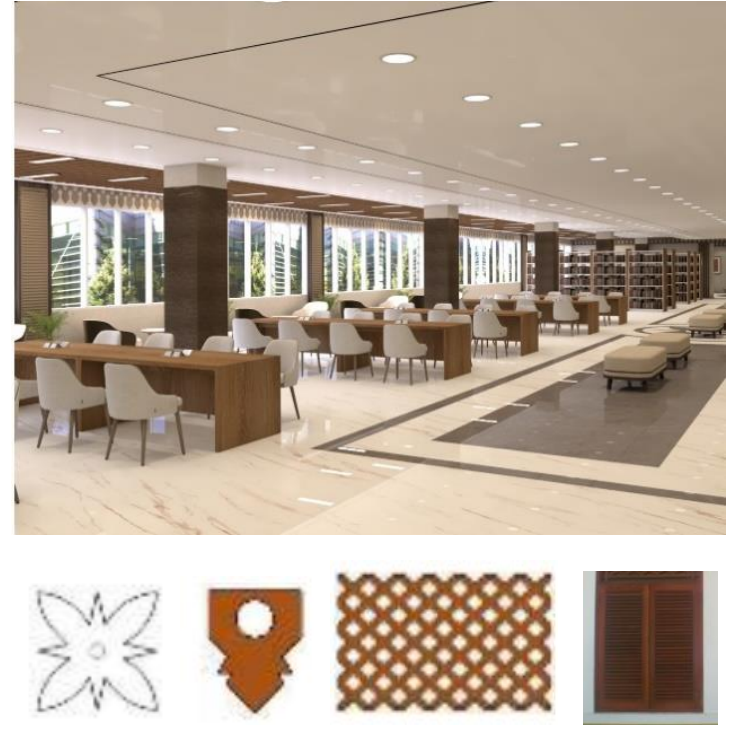

(a)

(b)

(c)

(d)

Gambar 7. Hasil Perancangan Interior Area Koleksi Pustaka Umum (Area koleksi). (a) Melati, (b) Gigi Balang, (c) tapak jalak, (d) krepyak/Jalusi

Dapat dilihat terdapat penggunaan pola lantai bermotif melati pada area koleksi pada ruang koleksi pustaka umum, dan penggunaan kombinasi tapak jalak dan melati pada area laser cuting pada rak buku. Pada area-area jarak antar jendela dihias dengan panel dengan model krepyak / jalusi. Sekeliling area ini pada pertemuan dinding dan plafon diterapkan ornamen gigi balang untuk memberikan nilai estetika lebih pada ruang. 


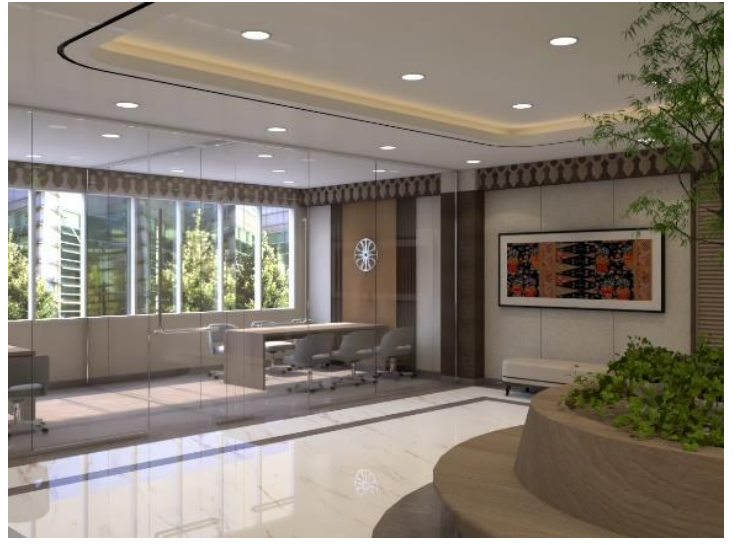

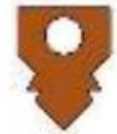

(a)

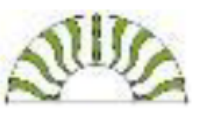

(b)
Gambar 8. Hasil Perancangan Interior Area Koleksi Pustaka Umum (Area ruang diskusi). (a) Gigi Balang, (b) Matahari

Pada area ruang diskusi pada area koleksi pustaka umum, terdapat motif hias matahari yang diletakkan pada area panel dinding yang terdapat disamping meja diskusi untuk memberikan unsur estetik pada ruang.

\section{IV.SIMPULAN}

Berdasarkan hasil penerapanpenerapan unsur hias arsitektur pada interior bergaya modern pada perancangan Perpustakaan Umum Daerah Provinsi DKI Jakarta - Cikini dapat disimpulkan bahwa unsur hias Betawi dapat memberikan nilai estetik lebih pada ruang dan disisi lain juga dapat memberikan unsur identitas kebudayaan lokal kedalam interior perpustakaan yang memberikan identitas pada interior terkait. Penelitian kali ini diharapkan dapat memberikan gambaran dan contoh penerapan ragam hias arsitektur Betawi kedalam gaya interior modern sehingga dapat menghidupkan kembali penggunaan ragam hias Betawi yang saat ini mulai berkurang di area Jakarta. Keterbatasan yang terdapat dalam kesempatan kali ini berupa kurangnya data yang dapat didapatkan dikarenakan kondisi pandemi saat ini yang membatasi kesempatan untuk mencari data-data yang lebih lengkap. Saran yang dapat diberikan peneliti pada saat ini bagi peneliti selanjutnya yang akan mengambil tema penelitian sejenis yaitu untuk dapat mencari sumber data yang lebih banyak dan lengkap lagi bagi penelitiannya.

\section{DAFTAR PUSTAKA}

Buku

Swadarma, D., \& Aryanto, Y. (2013). Rumah Etnik Betawi. Depok: Griya Kreasi.

Jurnal IImiah

Fajriyah, N. (2014). Revitalisasi

Perkampungan Budaya Betawidi Setu Babakan. Srengseng Sawah, Jakarta Selatan. Bogor: Departemen Arsitektur Lanskapfakultas Pertanianinstitut Pertanian Bogor. 
Kurniati, N., B. Amiuza, C., \& Suryasari, N. (2017). Transformasi Ornamen Rumah Betawi dalam Unsur-Unsur Ruang. Jurusan Arsitektur, Fakultas Teknik, Universitas Brawijaya.

Sheha, A. N., \& Ghoustanjiwani A.P. (2011). Lifestyle Tradisional Betawi dan Pengembangan Permukiman yang Mengakomodasikan Pariwisata di Setu Babakan. Jurusan Arsitektur, SAPPK, Institut Teknologi Bandung. 